\title{
Residencia: the annual inspection of households in an andean community
}

Residencia: inspección anual de casas en una comunidad andina

Residencia : l'Inspection annuelle des familles d'une communauté des Andes

\section{Steve Froemming}

\section{(2) OpenEdition}

\section{Journals}

Electronic version

URL: http://journals.openedition.org/bifea/3521

DOI: 10.4000/bifea.3521

ISSN: 2076-5827

\section{Publisher}

Institut Français d'Études Andines

Printed version

Date of publication: 1 December 2007

Number of pages: $353-360$

ISSN: 0303-7495

\section{Electronic reference}

Steve Froemming, «Residencia: the annual inspection of households in an andean community », Bulletin de l'Institut français d'études andines [Online], 36 (3) | 2007, Online since 01 June 2008, connection on 02 December 2020. URL : http://journals.openedition.org/bifea/3521 ; DOI : https:// doi.org/10.4000/bifea.3521

\section{(c)}

Les contenus du Bulletin de l'Institut français d'études andines sont mis à disposition selon les termes de la licence Creative Commons Attribution - Pas d'Utilisation Commerciale - Pas de Modification 4.0 International. 


\title{
Residencia: the annual inspection of households in an andean community
}

\author{
Steve Froemming*
}

\begin{abstract}
This paper provides ethnographic detail on a practice in the Andes known as residencia, the annual inspection of households by community officers in the traditional cargo system. Going house to house, newly-inaugurated officeholders look for signs of cleanliness, animal husbandry, discipline of children, ritual preparedness, religiosity, fertility, and charity. Garcilaso de la Vega reported on a similar practice carried out by Incan officials, but whether residencia is of Incan origin or arose post-Conquest remains unclear. While not as strict as it once was, residencia is still central to the celebration of the New Year.
\end{abstract}

Key words: Andes, civil-religious hierarchy, cargo system, Inca, peasant community, social control

\section{Residencia: inspección anual de casas en una comunidad andina}

\section{Resumen}

Este artículo presenta detalles etnográficos sobre una costumbre en los Andes conocida como residencia: la inspección anual de casas por autoridades de la comunidad dentro del sistema de cargos tradicionales. Las autoridades recién inauguradas van de casa en casa buscando indicios de aseo, atención a los animales domésticos, disciplina de los niños, preparación ritual, religiosidad, fertilidad, y caridad. Garcilaso de la Vega relata una práctica similar llevada a cabo por oficiales incaicos, pero no está claro si la residencia que practican hoy es de origen incaico o surgió después de la Conquista. Aunque la práctica de residencia ya no es tan estricta como antes, todavía es fundamental en la celebración del Año Nuevo.

Palabras clave: Andes, jerarquía civil y religiosa, sistema de cargos, Inca, comunidad campesina, control social

\footnotetext{
* Department of Social and Behavioral Sciences. Central Texas College (Killeen). E-mail: sjf@euskalnet.net
} 


\title{
Residencia : l'Inspection annuelle des familles d'une communauté des Andes
}

\author{
Résumé
}

Cet article fournit des détails ethnographiques sur une pratique andine connue sous le nom de residencia : il s'agit d'une inspection annuelle des familles par les autorités de la communauté à travers le système traditionnel du cargo. De maison en maison, les nouveaux titulaires de la charge contrôlent la propreté, le traitement donné aux animaux domestiques, l'éducation des enfants, le respect des rituels, la religiosité, la fertilité et la charité. Garcilaso de la Vega a rendu compte d'une pratique identique de la part des officiels incas, mais le fait que la residencia soit d'origine inca ou qu'elle soit postérieure à la conquête demeure incertain. Bien que moins rigoureuse qu'elle ne le fut, la residencia demeure un élément central de la célébration de la nouvelle année.

Mots clés : Andes, hiérarchie civile-religieuse, système du cargo, Inca, communauté paysanne, contrôle social

«[...] the same law provided that the Indians should dine and sup with their doors open so that the officials and judges should be able to inspect them freely. There were in fact certain judges appointed to inspect temples, public places and buildings, and private houses, and they were called

Ilactacamayu. These officials, either in person or through deputies, frequently visited the houses to

see that both husband and wife carefully and diligently kept the household and family in proper order and attended to the obedience, occupations, and needs of the children. The diligence of the couple was assessed by the adornment, cleanliness, and tidiness of the house, furniture, and clothes,

and even the pottery and other domestic utensils. Those who were regarded as careful and neat were rewarded with public commendation, while the careless were flogged on the arms and legs or punished in other ways as the law established». (Garcilaso de la Vega, 1987: 263-264)

\section{INTRODUCTION}

The inauguration of traditional authorities takes place on New Year's Day in Ccachín, a comunidad campesina (peasant community) in Cusco (Peru)1. The authorities — called varayoq (officeholders, staff-bearers) in Quechua for the staffs-of-office they carry - are rotated annually, and males are expected to take their turn when called upon, passing through a hierarchy of positions of increasing cost, responsibility, and prestige over the course of their lifetimes. Along with the investiture of officials come several days of communal activity and celebration. The incoming mayor (referred to locally as alcalde mayor or Inca alcalde) butchers a bull to serve to the entire community in a public feast, and sponsors wallata or Sargento dancers to accompany the new authorities². Once sworn

1 Ccachín is a comunidad campesina of some 250 families situated between 2300 and 4500 masl on the eastern slope of the Urubamba range of the southern Peruvian Sierra. Villagers are generally bilingual, with Quechua being the primary language of adults in both private and public contexts. Truck access to the area is relatively recent, with a bypass through Lares, the district capital, completed in the late 1980's. The ethnographic research on which this study is based was conducted from 1989 to 1992, with follow-up field work in 1998.

2 While villagers often use these terms for the dances interchangeably, they refer to two distinct dances in the region. Wallata is the one most often associated with this season and the neighboring puna communities of Ollantaytambo from which the dancers originate. It takes its name from an Andean goose (Chloephaga melanoptera Eyton), which is represented in the dance movements and the costumes the dancers wear. Both dances have to do with courtship, with young women taking the initiative in wallata and young men in Sargento. 
in, the varayoq spend the following days of the celebration going door-to-door through the village for what villagers call residencia, a ritual inspection of households.

Residencia as practiced in this contemporary Andean village bears a marked resemblance to the household inspections of the Inca described by Garcilaso de la Vega. But whether it is related by direct descent, emerged post-conquest to serve similar purposes, can be traced to antecedents in Spain, or arose entirely out of local interests and inventiveness is not clear. I'm unaware of other ethnographic accounts of household inspections in the Andes, and this report is motivated by the hope that in providing a description of the practice in one Andean village, ethnographers who have witnessed similar events elsewhere, as well as ethnohistorians able to point to related measures in the past, will help establish the practice's origins, pattern of distribution, variability, and persistence.

\section{THE CIVIL-RELIGIOUS HIERARCHY}

Ccachín has a dual political structure, as do most rural Andean communities. On one hand, there are the varayoq, traditional village authorities named for and empowered by the staffs of office (vara) that they bear. On the other hand, there are elected officials of the comunidad campesina proper and municipal offices that are legally mandated and nested in the hierarchy of local, regional, and national governments. The varayoq have their origins in pre-conquest Andean leadership, prestige, and power structures that were later legalized and reinforced by Viceroy Toledo in 1571. Over the last century, there have been numerous attempts to phase out traditional authorities in indigenous peasant communities, but in places such as Ccachín, participation in the varayoq system still carries considerable prestige and importance.

There are four levels to the varayoq system in Ccachín. They are hierarchically organized in terms of responsibility and status both within and between each level. The highest-ranking official in the system is the alcalde mayor or Inca alcalde. Immediately below him are three sub-mayors, the alcaldes de barrio. Below them are several alguaciles (constables). The lowest ranking positions in the hierarchy are occupied by three regidores (councilmembers). The varayoq are selected for a one-year term and pass the office on when their year is up, «resting» until they serve again at the next highest rank.

The varayoq have long been responsible to the teniente gobernador (the local representative of the provincial governor), and given the current organizational structure of the community, are also delegated tasks by the alcalde menor (the mayor of the municipality) and the president of the comunidad campesina. While community members expect the governing councils of the comunidad campesina and the municipality to provide new public works and contribute to the economic development of the community, they expect the Inca alcalde and his retinue to maintain common property, social order, and cultural traditions. The traditional authorities play an important role in communal management of the potato sectors, pastures, and woodlands. They respond to reports of animals causing damage in people's fields, patrol communal sectors where animals do not belong, and assess fines for damage to fields and crops. They are responsible for work parties related to agropastoral management and territorial integrity, including the planting and harvesting of potatoes on communal lands, building and repairing walls and fences around agricultural sectors, putting out wildfires, and surveying boundary markers.

The varayoq are expected to respond when a theft is reported, a fight breaks out, or an accident happens. They summon people to meet with judicial officers, and may be called on to resolve neighborhood conflicts. When attendance is low at a work party or an assembly, 
the varayoq round up absentees. The youngest members - the regidores - serve as town criers, regularly passing through the streets to call out information about assemblies, work parties, and community events. The varayoq play an important ceremonial role, especially at New Year and Carnival, and their presence serves to validate public functions throughout the year.

\section{RESIDENCIA: ANNUAL INSPECTION OF HOUSEHOLDS}

The custom of taking office on New Year's Day in Ccachín can be traced back to the $16^{\text {th }}$ century, when Viceroy Toledo issued an ordinance to that effect ${ }^{3}$. Once sworn in, the Inca alcalde sponsors a public feast, and the varayoq then go door-to-door through the village for the next three days heralding their tenure and inspecting all the households in Ccachín. Community leaders are first to be called upon, and the Quechua adjective hatun (bigger, greater) is applied to residencia the day the event is conducted at the homes of ranking officials. Huch'uy residencia (little residence inspection) is carried out for the communityat-large on succeeding days. During hatun residencia, the varayoq visit and inspect each other's homes, as well as those of the mayordomos (religious stewards) and civil officials. Feasted at each home, it's a time of orgiastic eating, drinking, coca exchange, prayer, and revelry. Huch'uy residencia is comparatively quieter, but still marked by the sharing of coca and alcohol that is the hallmark of Quechua sociability.

In anticipation of residencia, the occupants of each of the homes that the varayoq visit sweep and clean their house and decorate their shrine niche with a cross and flowers. Men and women wash their hair and change into clean clothing. Men put a chain with a crucifix around their neck, and fill their coca bags with coca leaves.

During hatun residencia, the varayoq move from house to house with a large entourage of dancers, helpers, and onlookers. As they enter a house, they are greeted by the heads of household, and hosts and guests kiss each other's crucifixes. The guests are served corn beer, alcohol, and coca, followed by a meal of lamb, guinea pig, corn tortillas, turnip greens, and squash. The varayoq leave their staff of office outside the door when they enter, and these are watched over by the regidores. The trumpeting of the conch shells of the regidores and the dancing of the wallata dancers mark the movement of the group through the community.

The most salient aspect of residencia - the first thing that residents report when asked to describe the event- is the inspection of households. As they enter, one of the varayoq may shake some grass or a tin with corn to see if the guinea pigs, chickens, and ducks are hungry and respond, or are already well-fed. While now a playful gesture, in the past, any animal that responded to the bait would be captured and taken to the home of the Inca alcalde, where it was kept and raised by the regidores who lived with him and served as his attendants. The animals would be slaughtered and eaten by the varayoq at Easter. People's homes are expected to be neat and clean for the visit, and if they are not, the varayoq may take steps to clean them. Women are expected to have their hair freshly combed. If they do not pass inspection, the varayoq may comb it, even roughly sometimes, with a horse brush. Punitive measures for negligence and slovenliness are occasionally still applied, but villagers emphasize that penalties were harsher and more frequent prior to agrarian reform.

3 In 1991, the swearing-in ceremony was moved up a day, since January 1 fell on a Tuesday, an inauspicious day of the week for such an event. In keeping with 16th-century European sorcery beliefs that diffused to the Andes and persist to the present day, certain important activities should not be initiated or conducted on a Tuesday or Friday. 
In addition to the survey of cleanliness and animal husbandry, the varayoq may ask to see any number of items associated with the material and spiritual well-being of the household. These include gear for the horses and mules (montura), a man's scarf and coca bag (chalina and ch'uspa, worn during rituals and by village officials), a comb and mirror for personal hygiene, a palm cross, lit candle, and religious calendar (the calendar - the «Almanaque del Qosqo»- helps people track religious feasts and doubles as a guide for naming their children after the saints), a woman's wedding ring (a sign that a couple is no longer cohabiting and has been married in the church), a doll (muñeca), representing fecundity and childcare), a riding whip (chicote, associated with the upbringing and discipline of children), and alms for widows and orphans (montepío). During their visit, the varayoq often ask couples if they are expecting to have a baby in the coming year.

The day after hatun residencia, the varayoq go door-to-door throughout the village for huch'uy residencia, a general inspection of the homes of all community members 4 . People are expected to be at home when the varayoq visit them, and most people choose to do tasks around their house or garden rather than to go out to work in the fields on this day. In the past, a community work party to clean the canals that carry drinking, cleaning, and gardening water to the houses was conducted, further ensuring that the men could be found close to home. With the construction of a piped-water system in the mid-1980s, the canals have become less important community-wide, and repairing and cleaning of each canal is most often taken on informally as needed by the individuals who most directly benefit from it. Huch'uy residencia is a scaled-down version of hatun residencia. The inspection of the households proceeds as the day before, but the dancers return to their homes, and a full meal is not served at each stop. If someone is not home when the varayoq stop by for huch'uy residencia, the varayoq write omiso (negligent, careless) with chalk on their door.

For the first two days, residencia takes place in Ccachín proper; on the third day, activity moves to the outlying hamlets. One of them, Qochayoq, has its own varayoq system, and after its traditional authorities are sworn into office in Ccachín, they return to Qochayoq to celebrate residencia on their own. The other, Rayankancha, is a newer settlement, and its two alguaciles are incorporated into the hierarchy of offices in Ccachín. On the third day of residencia, the two Rayankancha officeholders host the varayoq with a feast in Rayankancha. The varayoq call on all of the households of Rayankancha, visit the chapel there, and spend the rest of the day enjoying the meals and corn beer prepared for them at the homes of the Rayankancha alguaciles. The varayoq's trip to Rayankancha completes residencia and serves as the kacharpari (farewell) of the feast, bringing the New Year's inaugural to an end.

\section{DISCUSSION}

Residencia has many aspects —announcement, visitation, census, privacy management, social control, maintenance of public welfare, celebration - and without more historical data, there is no way of knowing if one objective or another played a primary role in its emergence. Like many activities, it continues to be conducted por costumbre («out of custom»), as villagers say, and the meaning and motivation may have changed through time.

The Inca-period household inspections described by Garcilaso de la Vega appear to foreshadow the contemporary practice of residencia. The Incan practice consisted of regular household inspections by officials to monitor the care that couples put into their

4 The event is also sometimes referred to as uña residencia (uña meaning «baby animal» in Quechua), perhaps for the animals that used to get carried away, perhaps to draw a metaphorical association between human and animal relations, perhaps for both reasons. 
homes, children, and belongings, with public praise for the diligent and punishment for the negligent. Contemporary household inspections in Ccachín are carried out annually by the traditional authorities of the community and focus on tokens of cleanliness (comb, mirror, grooming, proper attire, and swept floors), animal care (well-fed chickens and guinea pigs, and proper gear for the horses), religiosity (cross, candle, ecclesiastical calendar, and wedding ring), ritual preparedness and sociality (scarf and coca bag), fertility and childcare (signs of pregnancy, a doll, and a whip), and charity (alms). Whatever praise is given is witnessed by the entourage accompanying the varayoq, while punishment is limited to shaming, the marking of the doors of those absent with omiso as an indication of their negligence, and the indirect but significant effects of later gossip5.

The similarities between Incan household inspections and contemporary ones are not sufficient to establish a historical connection between the two, and even if it can ultimately be shown to have its origins in Andean antiquity, one must still ask what has sustained the practice through the centuries. It's worth noting that the local term for the practice - residencia - is Spanish, not Quechua, though it collocates with the Quechua adjectives hatun and huch'uy. Many of the objects requested for inspection were introduced by the Spanish, suggesting that even if the practice has Incan roots, it has evolved along with the daily life and material culture of Andean people.

It's possible that Incan and contemporary inspections are related by their social control function rather than by cultural descent. The hierarchical character of the custom leads one to wonder whose interests inspection served prior to agrarian reform, a time when it more clearly appears to have been motivated by social control than it does today: the mestizo authorities in Lares, the hacendados (hacienda owners) and their local administrators, the church, under the watchful eye of clergy centered in the district and the provincial capitals, community members in general, who stood to gain from the maintenance of certain standards of sanitation and conduct, or a combination of the above.

As Encinas Martín (1986) notes, before agrarian reform, the hacendados controlled the political power and forces of repression in the region, with the varayoq system an instrument largely serving their needs. Historically, the varayoq were at the whim of regional authorities, and practices that are now perceived as festive or innocuous by villagers may once have had a more onerous tone. Writing fifty-some years ago about life in Lares, the district capital, Gutiérrez reports that,

«The principal mission of the indigenous authorities is to tend to the [regional] authorities when they visit periodically, the priest at religious festivals, the municipal agent and the lieutenant governor for the annual division of land, or when the governor comes...they have to provide them foodstuffs for their larder such as chickens, potatoes, sheep, etc., products that they obtain free by collecting them in person with the regidores» (Gutiérrez Pareja, 1949: 6).

Likewise, Zúñiga Rivero writes,

«Usually, when the subprefect of the province visits these places, men who have had the fortune to carry out this office...let their rapacious instincts flow, and in concomitance with the governor, oblige the regidores to take chickens, sheep, pigs, etc. In this way, the faithful servants of justice are converted into instruments

5 The lashes to arms and legs that Garcilaso de la Vega reports as punishment for poor upkeep of the household in Inca times are not part of residencia. Also unlike the Inca era, while doors are usually kept open when eating during daylight hours for both practical and social reasons (much visiting occurs during these times, especially to arrange for reciprocal labor), there is no formal rule to this effect. 
of theft and unwitting accomplices of these evil politicians, who...capture...these posts to exploit them as they can, because it is understood that these posts are temporary» (Zúñiga Rivero, 1955: 10-11).

The varayoq's practice of making the rounds of the houses is documented in these earlier accounts, as is the expectation that they will confiscate animals. Neither of these authors mention residencia as such, but the custom is consistent with the way the local elites maintained and exercised their power. Before agrarian reform, the administrator of nearby hacienda lands is reported to have acted like an hacendado in Ccachín, taking centre position at the swearing in ceremony of the new varayoq, and using the traditional authorities to organize work parties in his own fields and for the hacendado.

Over the last forty years there has been increasing cultural, economic, and political contact between Ccachín and the provincial and departmental capitals, and the pace of change had quickened dramatically. Residencia appears to have grown and become more autonomous, but the ritual aspects have stayed much the same. With the village now having its own teniente gobernador, the varayoq no longer need to go to Lares, the district capital, to be sworn in, and the New Year's celebration has become more locally centered. With population growth and Rayancancha added as an annex, the number of households has grown substantially, amplifying the fiesta and the demands on the varayoq. No longer under the watchful eye of the administrator of the neighboring hacienda and district officers, the inspections have become more symbolic and light-hearted, and punishment has become rare. Perhaps as much as anything now, residencia serves to familiarize villagers with their new public servants, while allowing the varayoq to take informal census of the people they serve.

Some ritually important community traditions, such as the cleaning of canals and the inspection of community boundaries, are on the wane in Ccachín as they lose their original reason for being. The piped water system has largely replaced the canals, and official maps and legal actions now play a more prominent role than annual boundary inspections in territorial defense. On the other hand, some ceremonial events such as Carnival, the pilgrimage of Qoyllur Rit'i, and celebration of the community's anniversary have grown in importance, the first an indication of the evolving cultural identity (Carnival Sunday is known as Misti Carnaval — «Mestizo Carnival»— from which it borrows its form), the second made possible by the growing truck access, and the third, commemorating a central but relatively new institution, the comunidad campesina. While residencia - like the traditional authority system it is premised on — has thus-far proven relatively resilient, it's more closely related to the first group of traditions than the second, and I expect that its days are likewise numbered. For one thing, its fate is linked to the survival of the traditional civil-religious hierarchy as a whole. For another, it may fall victim to increasing social differentiation, and to the resulting changes in cultural expectations about privacy and control.

House inspections by traditional authorities at the start of the New Year in Ccachín are complex syncretic blends of activities, objects, and roles dating from pre-Columbian to present times. Determining the origins of the tradition itself, as well as the social forces and meanings that have sustained it through time and shaped its present form, requires more distributional and historical data than an ethnography of a single community can provide. Introducing the practice here is but the first step toward bringing information scattered about in ethnographies and historical accounts together, and in pooling knowledge for region-wide comparison. 


\section{Acknowledgments}

Funding for my research in the Andes has been provided by the National Science Foundation, Organization of American States, Jackson School of International Studies, and the Graduate School of the University of Washington. I'm very grateful to the community of Ccachín and to all in Peru, Spain, and the U.S. who have made my research possible. Special thanks go to Daniel Embregts of HeZee Translation for providing the French translation of the abstract.

\section{References cited}

ENCINAS MARTÍN, A., 1986 - Organizaciones populares y cambio social. La Convención y Lares (1944 a 1984), 62 p.; Cusco: Centro de Estudios Rurales Andinos «Bartolomé de las Casas».

GARCILASO DE LA VEGA, I., 1987 - Royal commentaries of the Incas and general history of Peru (H. V. Livermore, ed.), 232 p.; Austin: University of Texas Press.

GUTIÉRREZ PAREJA, S., 1949 - Lares, sus habitantes y sus autoridades; Cusco: Universidad Nacional San Antonio Abad del Cusco (Archivo Departamental del Cusco). Unpublished monograph from the course «Geografía humana general del Perú» (J. Cornejo Bouroncle, instructor).

ZÚÑIGA RIVERO, A. W., 1955 - Untitled [Los varayoq de Lares]; Cusco: Universidad Nacional San Antonio Abad del Cusco (Archivo Departamental del Cusco). Unpublished monograph from the course «Geografía humana general del Perú» (J. Cornejo Bouroncle, instructor). 